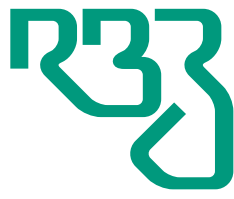

Revista

Brasileira de

Zootecnia

Brazilian Journal of Animal Science

ISSN 1806-9290

www.rbz.org.br

\title{
Genetic variability of tambaqui broodstocks in the Brazilian state of Pará
}

\author{
Leandro de Araújo Ferreira ${ }^{1}$, Paola Fabiana Fazzi-Gomes ${ }^{1,2}$ (iD, \\ Sávio Guerreiro $^{1}$ (iD), Marília Danyelle Nunes Rodrigues ${ }^{3}$ (iD), Ândrea Kely \\ Ribeiro-dos-Santos² iD, Sidney Santos², Igor Hamoy ${ }^{1 *}$ iD \\ ${ }^{1}$ Universidade Federal Rural da Amazônia, Instituto Socioambiental e dos Recursos \\ Hídricos, Laboratório de Genética Aplicada, Belém, PA, Brasil. \\ ${ }^{2}$ Universidade Federal do Pará, Centro de Ciências Biológicas, Laboratório de Genética \\ Humana e Médica, Belém, PA, Brasil \\ ${ }^{3}$ Universidade Federal Rural da Amazônia, Campus de Parauapebas, Parauapebas, PA, Brasil.
}

\begin{abstract}
*Corresponding author: igorhamoy@ufra.edu.br

Received: May 22, 2018

Accepted: March 16, 2019

How to cite: Ferreira, L. A.; Fazzi-Gomes,

P. F.; Guerreiro, S.; Rodrigues, M. D. N.;

Ribeiro-dos-Santos, A. K.; Santos, S. and

Hamoy, I. 2019. Genetic variability of tambaqui

broodstocks in the Brazilian state of Pará.

Revista Brasileira de Zootecnia 48:e20180106.

https://doi.org/10.1590/rbz4820180106

Copyright: This is an open access article distributed under the terms of the

Creative Commons Attribution License

(http://creativecommons.org/licenses/by/4.0/),

which permits unrestricted use, distribution,

and reproduction in any medium, provided the

original work is properly cited.
\end{abstract}

\section{(cc) BY}

\begin{abstract}
The present study evaluated the genetic variability of the broodstocks of tambaqui hatcheries in the Brazilian state of Pará. Samples were obtained from the caudal fin of 110 broodstocks from one hatchery in each of four municipalities (Santarém, Peixe-Boi, Breu-Branco, and Ulianópolis), representing all the individuals of each hatchery stock. The samples were genotyped using the multiplex system microsatellite markers. Data were used to calculate observed and expected heterozygosity, number of alleles per locus, and allelic richness. The effective population size and inbreeding coefficient were also calculated. The genetic differentiation between populations was evaluated by using $\mathrm{F}_{\mathrm{ST}}$, and population structuring by the most likely number of genetically homogenous populations and Unweighted Pair Group Method (UPGMA); the arithmetic means were based on Nei's. The indices indicated a loss of genetic variability in the broodstocks from Ulianópolis, Peixe-Boi, and Breu-Branco in comparison with wild tambaqui populations, although this was not apparent in the Santarém stock. A moderate level of genetic differentiation was found among the tambaqui broodstocks based on the $\mathrm{F}_{\mathrm{ST}}$ estimates, which were reinforced by the structuring found in the Bayesian analysis and UPGMA. This reflects the domestication process, given that no such structuring is found in natural tambaqui populations. This moderate genetic differentiation associated with the loss of genetic variability found in the four tambaqui broodstocks from the state of Pará provides important insights for the development of future programs of genetic improvement, as well as the conservation of the genetic diversity of these stocks.
\end{abstract}

Keywords: Colossoma macropomum, fish, genetic diversity, hatcheries

\section{Introduction}

Tambaqui (Colossoma macropomum) is the most intensively-farmed native fish species in Brazil, with a total production of 136,990 tons in 2016 (IBGE, 2016). Tambaqui farming is considered an important alternative for the exploitation of the wild stocks of this species, and, given the economic importance of the species on both regional and national levels, it has been included in the Brazilian Program of Genetic Improvement (Lopes et al., 2009).

Understanding the genetic variability of captive stocks is fundamental to any program of genetic improvement (Moreira et al., 2007) or species conservation. The loss of genetic variability in farmed 
stocks has negative implications for a range of economically important parameters, such as survival and growth, as well as the loss of adaptive potential. Molecular markers such as microsatellites have proven to be efficient indicators for the measurement of genetic variation both within and among farmed fish stocks (Mojekwu and Anumudu, 2013).

Systematic data on the standard breeding practices of a hatchery are required to guarantee the long-term viability of cultivated stocks by maintaining diversity and minimizing inbreeding (An et al., 2013). In this context, the present study determined the genetic variability of tambaqui broodstocks from four hatcheries in the Brazilian state of Pará.

\section{Material and Methods}

The original project of the present study was submitted for evaluation to the Ethics Committee and received approval through case no. 031/2013 (CEUA) - 23084.008077/2013-73.

Samples were obtained from the caudal fins of 110 tambaqui broodstocks from one hatchery in each of four municipalities, representing all the individuals of each hatchery stock, that is, Santarém

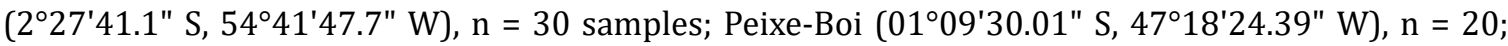

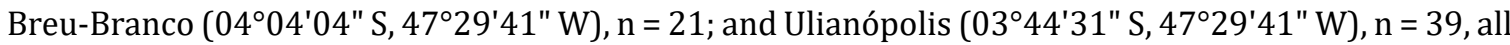
located in the state of Pará, in northern Brazil. The commercial broodstocks of Peixe-Boi, Breu-Branco, and Ulianopólis were established from captive stocks, whereas that from Santarém was formed by native animals captured in the lower Amazon River. The broodstocks were between six and eight years old, with a mean weight of $6 \mathrm{~kg}$, and have been used for reproduction since their sexual maturation at three years of age. None of the individuals had a registered pedigree or any record of their animal performance.

The DNA was extracted using a Genomic DNA Isolation kit (Norgen Biotek Corporation). The amount of DNA in the samples was determined using a NanoDrop ${ }^{\mathrm{TM}}$ ND-1000 spectrophotometer (Thermo Scientific), and once measured, the samples were standardized to a concentration of $5 \mathrm{ng} / \mathrm{uL}$. The samples were genotyped using the multiplex system for 10 microsatellite markers (Cmacr $\mu 01-H M 579948$,

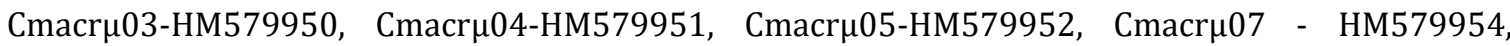

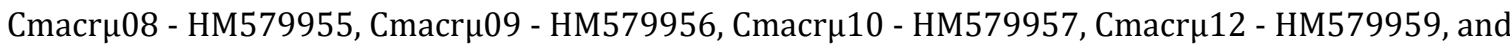
Cmacru13 - HM579960) developed by Hamoy and Santos (2012).

The PCR were standardized to a final volume of $8 \mu \mathrm{L}$ containing $6.5 \mu \mathrm{L}$ 2X QIAGEN ${ }^{\circledR}$ Multiplex PCR Master mix (Qiagen), $0.5 \mu \mathrm{L}$ of each primer, and $1.0 \mu \mathrm{L}$ of DNA. The samples were amplified in a Veriti thermocycler (Applied Biosystems), based on the following protocol: initial denaturation at $95^{\circ} \mathrm{C}$ for $15 \mathrm{~min}$, followed by $10 \mathrm{cycles}$ of $94^{\circ} \mathrm{C}$ for $30 \mathrm{~s}, 60^{\circ} \mathrm{C}$ for $90 \mathrm{~s}$, and $72{ }^{\circ} \mathrm{C}$ for $60 \mathrm{~s}$, with a final extension at $72{ }^{\circ} \mathrm{C}$ for $60 \mathrm{~min}$.

The PCR products $(1 \mu \mathrm{L})$ were mixed with $8.5 \mu \mathrm{L}$ of Hi-Di deionized formamide (Applied Biosystems) and $0.5 \mu \mathrm{L}$ of $500 \mathrm{LIZ}$ Gene Scan (Applied Biosystems) for viewing in an Applied Biosystems 3130 automatic capillary sequencer. The individuals were genotyped in the Gene Mapper 3.7 program (Applied Biosystems).

Micro-Checker 2.2.3 was used to determine possible genotyping errors and the presence of null alleles, and the Polymorphic Information Content (PIC) was calculated in Cervus 3.0, using Botstein et al. (1980) classification system, in which values of less than 0.25 indicate low polymorphism; those of 0.25-0.5, a moderate level of polymorphism; and those higher than 0.5 , a highly polymorphic locus.

Observed $\left(\mathrm{H}_{0}\right)$ and expected $\left(\mathrm{H}_{\mathrm{E}}\right)$ heterozygosity and their possible deviations from Hardy-Weinberg equilibrium (HWE) were calculated in the Arlequin 3.5.1.3 program, followed by the determination of the P-values for the Bonferroni correction (Rice, 1989). The number of alleles per locus $\left(\mathrm{N}_{\mathrm{A}}\right)$ and allelic richness $\left(A_{R}\right)$ were all estimated using Fstat version 2.9.3.2. The effective population size (Ne) was estimated based on linkage equilibrium approach of Waples and Do (2008), run in Ne Estimator 2.01, 
with a minimum allelic frequency of 0.02 , and a $95 \%$ parametric confidence interval. The inbreeding coefficient was estimated as $\mathrm{F}=1 / 2 \mathrm{Ne}$.

The genetic differentiation between populations was evaluated using $\mathrm{F}_{\mathrm{S} \text {, }}$, run in Arlequin 3.5.1.3. To infer the most likely number of genetically homogenous populations (K), the database was analyzed using the Structure 2.2 program. This Bayesian analysis was based on $10^{6}$ simulations with $\mathrm{K}$ values ranging from 1 to 4 , and a burn-in of 20,000 simulations. The most likely value of $\mathrm{K}$ was determined by the $\Delta \mathrm{K}$ method described by Evanno et al. (2005), which was run in Structure Harvester 0.6.94. An Unweighted Pair Group Method (UPGMA) tree was obtained from the arithmetic means based on genetic distance of Nei (1978), run in GDA 1.1.

\section{Results}

The results of the Micro-Checker analysis indicated that there were no null alleles or stutter bands in the dataset. The PIC was more than 0.5 for all markers, that is, extremely informative.

A total de 105 alleles were recorded for the 10 loci analyzed, based on the samples obtained from the 110 tambaqui broodstocks. The Santarém broodstock had the highest mean $\mathrm{N}_{\mathrm{A}}$ (8.4), followed by Peixe-Boi (5.3), Ulianópolis (5.0), and Breu Branco (5.0). The same pattern was recorded for the mean $A_{R}$ : Santarém (7.5), Peixe-Boi (5.3), Breu-Branco (4.9), and Ulianópolis (4.6) (Table 1).

Higher mean $\mathrm{H}_{0}$ values were registered in Santarém, Peixe-Boi, and Breu Branco (0.7), and lower in Ulianópolis (0.6). Mean $\mathrm{H}_{\mathrm{E}}$ was higher in Santarém (0.8) and Peixe-Boi (0.7), and lower in Ulianópolis and Breu Branco (0.6). Most of the loci were in HWE, with two markers (Cmacr $\mu 5$ and Cmacru12) being out of equilibrium due to a deficiency of heterozygotes (Table 1).

The smallest $\mathrm{Ne}$ and highest inbreeding coefficients were recorded in Ulianópolis $(\mathrm{Ne}=14.3$ and $\mathrm{F}=0.0350)$ and Breu Branco $(\mathrm{Ne}=11.2$ and $\mathrm{F}=0.0446)$. The highest mean $\mathrm{Ne}(117.4)$ and lowest inbreeding coefficient $(\mathrm{F}=0.0043)$ were recorded in Santarém, followed by Peixe-Boi $(\mathrm{Ne}=24$ and $\mathrm{F}=0.0208$ ) (Table 2).

The $\mathrm{F}_{\mathrm{ST}}$ values indicated a differentiation of 0.07 between the broodstocks of Santarém and Peixe-Boi, 0.09 for Santarém vs. Ulianópolis, 0.10 for Peixe-Boi vs. Ulianópolis, 0.11 for Santarém vs. Breu-Branco and Breu-Branco vs. Urianópolis, and 0.12 for Peixe-Boi vs. Breu-Branco. The Bayesian analysis indicated the existence of two clusters $(\mathrm{K}=2)$ in the database analyzed, one formed by the broodstocks from Santarém and Peixe-Boi, and the other by the broodstocks from Breu-Branco and Ulianópolis, a pattern corroborated by the UPGMA analysis (Figure 1).

Table 1 - Genetic diversity index of tambaqui broodstocks from the Brazilian state of Pará

\begin{tabular}{|c|c|c|c|c|c|c|c|c|c|c|c|c|c|c|c|c|}
\hline \multirow{2}{*}{ Loci } & \multicolumn{4}{|c|}{ Santarém $(\mathrm{N}=30)$} & \multicolumn{4}{|c|}{ Peixe-Boi $(\mathrm{N}=20)$} & \multicolumn{4}{|c|}{ Breu Branco $(\mathrm{N}=21)$} & \multicolumn{4}{|c|}{ Ulianópolis $(\mathrm{N}=39$ ) } \\
\hline & $\mathrm{N}_{\mathrm{A}}$ & $A_{R}$ & $\mathrm{H}_{0}$ & $\mathrm{H}_{\mathrm{E}}$ & $\mathrm{N}_{\mathrm{A}}$ & $A_{R}$ & $\mathrm{H}_{0}$ & $\mathrm{H}_{\mathrm{E}}$ & $\mathrm{N}_{\mathrm{A}}$ & $A_{R}$ & $\mathrm{H}_{0}$ & $\mathrm{H}_{\mathrm{E}}$ & $\mathrm{N}_{\mathrm{A}}$ & $A_{R}$ & $\mathrm{H}_{0}$ & $\mathrm{H}_{\mathrm{E}}$ \\
\hline Cmacr $\mu 1$ & 5 & 4.6 & 0.6 & 0.6 & 4 & 4 & 0.4 & 0.5 & 2 & 2 & 0.4 & 0.4 & 3 & 3 & 0.6 & 0.5 \\
\hline Стасr $\mu 03$ & 6 & 5.7 & 0.7 & 0.7 & 3 & 3 & 0.6 & 0.6 & 6 & 6 & 0.9 & 0.7 & 6 & 5.3 & 0.5 & 0.5 \\
\hline Cmacr $\mu 04$ & 10 & 8.9 & 0.9 & 0.9 & 6 & 6 & 0.8 & 0.8 & 5 & 5 & 0.6 & 0.6 & 5 & 4.8 & 0.8 & 0.7 \\
\hline Cmacr $\mu 55$ & 7 & 6.8 & 0.7 & 0.8 & 4 & 4 & 0.7 & 0.7 & 4 & 4 & 0.9 & 0.6 & 4 & 4 & $0.6^{*}$ & $0.7^{*}$ \\
\hline Cmacr $\mu 07$ & 12 & 10.3 & 0.8 & 0.8 & 9 & 9 & 0.8 & 0.8 & 9 & 8.7 & 0.9 & 0.7 & 8 & 6.6 & 0.6 & 0.7 \\
\hline Стасr $\mu 08$ & 9 & 7.7 & 0.5 & 0.8 & 5 & 5 & 0.8 & 0.7 & 3 & 3 & 0.7 & 0.5 & 4 & 3.9 & 0.5 & 0.6 \\
\hline Стасr $\mu 09$ & 9 & 7.8 & 0.8 & 0.8 & 4 & 4 & 0.7 & 0.6 & 7 & 6.9 & 0.9 & 0.7 & 6 & 5.2 & 0.7 & 0.7 \\
\hline Cmacr $\mu 10$ & 7 & 6.3 & 0.8 & 0.8 & 5 & 5 & 0.8 & 0.7 & 4 & 4 & 0.8 & 0.7 & 4 & 3.9 & 0.5 & 0.5 \\
\hline Стасr $\mu 12$ & 12 & 10.5 & $0.6^{*}$ & $0.9^{*}$ & 7 & 7 & $0.3^{*}$ & $0.7^{*}$ & 5 & 5 & 0.5 & 0.7 & 7 & 6.5 & $0.5^{*}$ & $0.7^{*}$ \\
\hline Cmacru13 & 7 & 6.6 & 0.8 & 0.7 & 6 & 6 & 0.7 & 0.7 & 5 & 4.9 & 0.6 & 0.5 & 3 & 2.5 & 0.4 & 0.5 \\
\hline Mean & 8.4 & 7.5 & 0.7 & 0.8 & 5.3 & 5.3 & 0.7 & 0.7 & 5 & 4.9 & 0.7 & 0.6 & 5 & 4.6 & 0.6 & 0.6 \\
\hline
\end{tabular}

$N_{A}$ - number of alleles per locus; $A_{R}$ - allelic richness; $H_{O}$ - observed heterozygosity; $H_{E}$ - expected heterozygosity. * Marker out of the Hardy-Weinberg equilibrium, after Bonferroni correction (adjusted P-value $<0.005$ ). 
Table 2 - Sample size (N), effective population size (Ne), confidence interval (CI), and inbreeding coefficient (F) for the four Colossoma macropomum hatcheries analyzed in the present study

\begin{tabular}{lcccc}
\hline Population & $\mathrm{N}$ & $\mathrm{Ne}$ & $95 \% \mathrm{Cl}$ & $\mathrm{F}=1 / 2 \mathrm{~N}_{\mathrm{e}}$ \\
\hline Santarém & 30 & 117.4 & $(56.1-2292.4)$ & 0.0043 \\
Peixe-Boi & 20 & 24 & $(14.1-53.5)$ & 0.0208 \\
Breu Branco & 21 & 11.2 & $(7.3-17.6)$ & 0.0446 \\
Ulianópolis & 39 & 14.3 & $(10.5-19.6)$ & 0.0350 \\
\hline
\end{tabular}

A

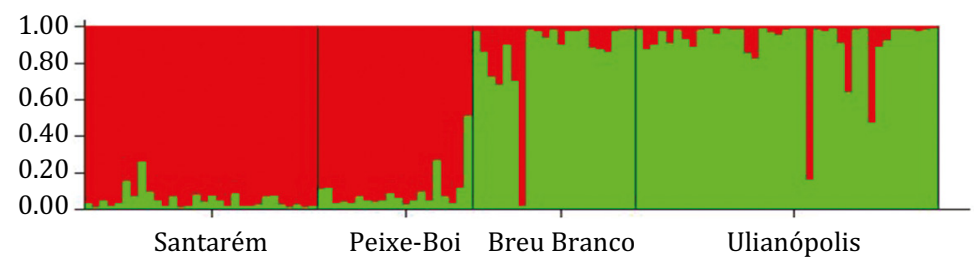

B

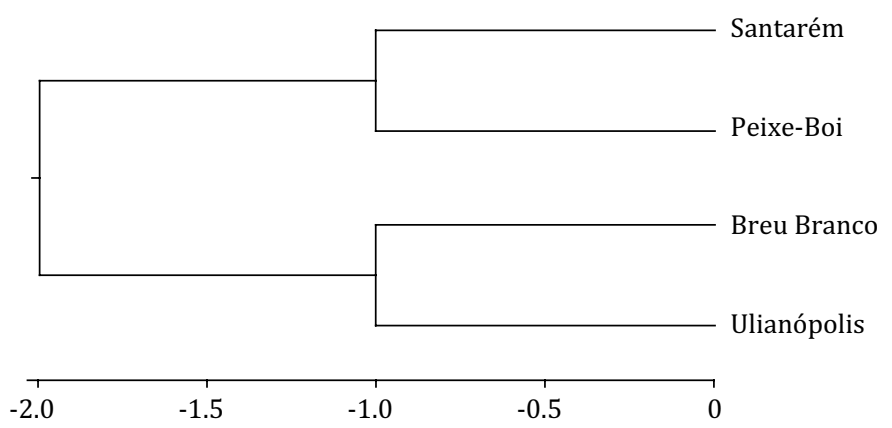

Figure 1 - Standard population structure (A) in tambaqui broodstocks from four hatcheries, supported by STRUCTURE, indicating the existence of two groups $(\mathrm{K}=2)$ based on 10 microsatellite $(\mathrm{B})$ patterns corroborated by Unweighted Pair Group Method (UPGMA), and arithmetic means based on Nei's.

\section{Discussion}

A loss of genetic variability was detected in the Ulianópolis, Peixe-Boi, and Breu-Branco broodstocks in comparison with those of the wild tambaqui populations from the Amazon basin described by Hamoy et al. (2011), based on the analysis of 20 individuals from the lower Amazon, and by Fazzi-Gomes et al. (2017), who analyzed 247 individuals from Manaus and Santarém, based on the set of microsatellite markers analyzed in the present study. As these broodstocks were formed from captive individuals, it seems likely that this loss of genetic variability reflected the low variability of the stocks from which these broodstocks were derived, reflecting the loss of the natural genetic variation of the population through the domestication process.

The stock from Santarém analyzed in the present study presented relatively high indices of genetic variability, as recorded by Aguiar et al. (2018) for a second broodstock in the same region, which according to the authors, indicates that these broodstocks were established, and possibly also restocked, with wild-caught individuals. This is an important factor that should be considered for the establishment and maintenance of farm broodstocks.

The loss of variability is emphasized most clearly by the $A_{R}$ values, given that $A_{R}$ is not biased by sample size (Spencer et al., 2000), when the values recorded in the present study are compared with those found in a wild population by Hamoy et al. (2011), who recorded an $A_{R}$ value of 9 , while 
Fazzi-Gomes et al. (2017) registered $A_{R}$ of 8.6, indicating higher levels of genetic variability in the wild populations.

Gonçalves et al. (2018), Aguiar et al. (2018), and Santos et al. (2016) also found evidence of the loss of genetic variability in tambaqui broodstocks from a number of different regions of Brazil. The authors attributed these low values to a process of genetic drift, resulting from the small effective size of the breeding populations found in the tambaqui farms, a practice adopted to minimize production costs, and the lack of any genetic management.

Effective population size is an important parameter for the evaluation of farmed fish stocks, because it determines the potential for genetic drift in a population which, in turn, influences the rate of loss of genetic diversity, rate of fixation of deleterious alleles, and potential for the maintenance of beneficial alleles through selective processes (Berthier et al., 2002). The effective numbers recorded in Ulianópolis, Breu Branco, and Peixe-Boi were lower than expected, i.e., 50-100, as observed by Aguiar et al. (2018), a value that would require improvement, given the risks associated with low Ne.

The inbreeding coefficient was within the limits recommended by Tave (1999), that is, below 0.05 , for the avoidance of inbreeding depression, which was probably due to the fact that the broodstocks had been formed only a short time prior to the study. Except for Santarém, none of the broodstocks appears to have levels of genetic variability adequate for the avoidance of inbreeding depression over the long term.

The tambaqui broodstocks analyzed here presented a moderate degree of genetic differentiation, based on the $\mathrm{F}_{\mathrm{ST}}$ values, which were all higher than 0.05 (see Hartl and Clark, 2010). This moderate level of differentiation is supported by the structuring recorded in the Bayesian analysis $(\mathrm{K}=2)$ and UPGMA, which reflects the domestication process, given that structuring is not found in the natural tambaqui populations, as confirmed by Fazzi-Gomes et al. (2017), using the same microsatellite markers as those used in the present study.

\section{Conclusions}

This moderate genetic differentiation associated with the loss of genetic variability found in the four tambaqui broodstocks from the Brazilian state of Pará provide important insights for future programs of genetic improvement, as well as the conservation of the genetic diversity of these stocks. These findings indicate that an increase in gene flow would be advisable, in particular through the integration of wild-caught specimens in the breeding stocks of the tambaqui farms analyzed in the present study. In addition to being a highly effective tool for the evaluation of the genetic diversity of broodstocks, molecular microsatellite markers may also contribute to the genetic management of stocks, helping to avoid the loss of genetic variability through the identification of less closely related breeders, in genetic terms. This would ensure the maximum possible genetic variability of the broodstocks, while also minimizing the levels of endogamy.

\section{Conflict of Interest}

The authors declare no conflict of interest.

\section{Author Contributions}

Conceptualization: L.A. Ferreira, P.F. Fazzi-Gomes and I. Hamoy. Data curation: L.A. Ferreira and P.F. Fazzi-Gomes. Funding acquisition: A.K. Ribeiro-dos-Santos, S. Santos and I. Hamoy. Investigation: L.A. Ferreira and P.F. Fazzi-Gomes. Methodology: L.A. Ferreira, P.F. Fazzi-Gomes, S. Guerreiro and M.D.N. Rodrigues. Project administration: P.F. Fazzi-Gomes, S. Santos and I. Hamoy. Resources: M.D. N. Rodrigues, A.K. Ribeiro-dos-Santos, S. Santos and I. Hamoy. Supervision: A.K. Ribeiro-dos-Santos, S. Santos and 
I. Hamoy. Writing-original draft: L.A. Ferreira and P.F. Fazzi-Gomes. Writing-review \& editing: L.A. Ferreira, P.F. Fazzi-Gomes, M.D.N. Rodrigues, S. Santos and I. Hamoy.

\section{Acknowledgments}

This research was supported by Conselho Nacional de Desenvolvimento Científico e Tecnológico (CNPq), Financiadora de Estudos e Projetos (FINEP), Fundação Amazônia de Amparo a Estudos e Pesquisas (FAPESPA; Programa Primeiros Projetos - PPP - FAPESPA/CNPq/007/2013), and Pró-Reitoria de Pesquisa e Desenvolvimento Tecnológico (PROPED) of the Universidade Federal Rural da Amazônia.

\section{References}

Aguiar, J. P.; Fazzi-Gomes, P. F.; Hamoy, I. G.; Santos, S. E. B.; Schneider, H. and Sampaio, I. 2018. Loss of genetic variability in the captive stocks of tambaqui, Colossoma macropomum (Cuvier, 1818), at breeding centres in Brazil, and their divergence from wild populations. Aquaculture Research 49:1914-1925. https://doi.org/10.1111/are.13647

An, H. S.; Shin, E. H.; Lee, J. W.; Nam, M. M.; Myeong, J. I. and An, C. M. 2013. Comparative genetic variability between broodstock and offspring populations of Korean starry flounder used for stock enhancement in a hatchery by using microsatellite DNA analyses. Genetics and Molecular Research 12:6319-6330. https://doi.org/10.4238/2013.December.4.19

Berthier, P.; Beaumont, M. A.; Cornuet, J. M. and Luikart, G. 2002. Likelihood-based estimation of the effective population size using temporal changes in allele frequencies: a genealogical approach. Genetics 160:741-751.

Botstein, D.; White, R. L.; Skolnick, M. and Davis, R. W. 1980. Construction of a genetic linkage map in man using restriction fragment length polymorphisms. The American Journal of Human Genetics 32:314-331.

Evanno, G.; Regnaut, S. and Goudet, J. 2005. Detecting the number of clusters of individuals using the software STRUCTURE: a simulation study. Molecular Ecology 14:2611-2620. https://doi.org/10.1111/j.1365-294X.2005.02553.x

Fazzi-Gomes, P. F.; Guerreiro, S.; Palheta, G. D. A.; Melo, N. F. A. C.; Santos, S. and Hamoy, I. 2017. High genetic diversity and connectivity in Colossoma macropomum in the Amazon basin revealed by microsatellite markers. Genetics Molecular Biology 40:142-146. https://doi.org/10.1590/1678-4685-gmb-2015-0222

Gonçalves, R. A.; Santos, C. H. A.; Sá Leitão, C. S.; Souza, E. M. S. and Almeida-Val, V. M. F. 2018. Genetic basis of Colossoma macropomum broodstock: Perspectives for an improvement program. Journal of the World Aquaculture Society 1-12. https://doi.org/10.1111/jwas.12564

Hamoy, I. G. and Santos, S. 2012. Multiplex PCR panel of microsatellite markers for the tambaqui, Colossoma macropomum, developed as a tool for use in conservation and broodstock management. Genetics Molecular Research 11:141-146. https://doi.org/10.4238/2012.January.26.1

Hamoy, I. G.; Cidade, F. W.; Barbosa, M. S.; Gonçalves, E C. and Santos, S. 2011. Isolation and characterization of tri and tetranucleotide microsatellite markers for the tambaqui (Colossoma macropomum, Serrasalmidae, Characiformes). Conservation Genetics Resources 3:33-36. https://doi.org/10.1007/s12686-010-9275-5

Hartl, D. L. and Clark, A. G. 2010. Principles of population genetics. 3rd ed. Sunderland, MA.

IBGE - Instituto Brasileiro de Geografia e Estatística. 2016. Produção da Pecuária Municipal. Available at: <https://biblioteca.ibge.gov.br/visualizacao/periodicos/84/ppm_2016_v44_br.pdf>. Accessed on: Aug. 22, 2018.

Lopes, T. S.; Streit Jr., D. P.; Ribeiro, R. P.; Povh, J. A.; Lopera-Barrero, N. M.; Vargas, L.; Pinto Filho, C. and Queiroz, J. R. 2009. Diversidade genética de estoques de reprodutores de Colossoma macropomum. Arquivo Brasileiro de Medicina Veterinária e Zootecnia 61:728-735. https://doi.org/10.1590/S0102-09352009000300029

Mojekwu, T. O. and Anumudu, C. I. 2013. Microsatellite markers in aquaculture: Application in fish population genetics. Journal of Environmental Science, Toxicology and Food Technology 5:43-48.

Moreira, A. A.; Hilsdorf, A. W. S.; Silva, J. V. and Souza, V. R. 2007. Variabilidade genética de duas variedades de tilápia nilótica por meio de marcadores microssatélites. Pesquisa Agropecuária Brasileira 42:521-526. https://doi.org/10.1590/S0100-204X2007000400010

Nei, M. 1978. Estimation of average heterozygosity and genetic distance from a small number of individuals. Genetics 89:583-590.

Rice, W. R. 1989. Analyzing tables of statistical tests. Evolution 43:223-225.

Santos, C. H. A.; Santana, G. X.; Sá Leitão, C. S.; Paula-Silva, M. N. and Almeida-Val, V. M. F. 2016. Loss of genetic diversity in farmed populations of Colossoma macropomum estimated by microsatellites. Animal Genetics 47:373-376. https://doi.org/10.1111/age.12422

R. Bras. Zootec., 48:e20180106, 2019 
Spencer, C. C.; Neigel, J. E. and Leberg, P. L. 2000. Experimental evaluation of the use fullness of microsatellite DNA for detecting demographic bottlenecks. Molecular Ecology 9:1517-1528.

Tave, D. 1999. Inbreeding and brood stock management. Fisheries Technical Paper, No. 392. Rome.

Waples, R. S. and Do, C. 2008. LDNE: A program for estimating effective population size from data on linkage disequilibrium. Molecular Ecology Resources 8:753-756. https://doi.org/10.1111/j.1755-0998.2007.02061.x 